\title{
«ТЕПЕРЬ УЖЕ ЧАСТЬ ДОРОГОЙ РОССИИ»: ПРАЗДНОВАНИЕ 300-ЛЕТНЕГО ЮБИЛЕЯ ДОМА РОМАНОВЫХ В УЗБЕКИСТАНЕ
}

\section{"NOW PART OF DEAR RUSSIA": CELEBRATION OF THE 300TH ANNIVERSARY OF THE ROMANOV DYNASTY IN UZBEKISTAN}

A. Ryzhova

Summary: The article is devoted to the celebrations in honor of the 300th anniversary of the Romanov dynasty in the Syrdarya, Fergana and Samarkand regions. On the basis of archival documents and periodicals, jubilee events were recreated among the Russian population and among the "natives". They were supposed to facilitate the merger of the Turkestan region with other parts of the empire. The local population passively, but with interest, participated in the holiday of the "White Czar".

Keywords: commemorative policy, the Romanov dynasty, the 300th anniversary of the dynasty, Uzbekistan, Syrdarya region, Fergana region, Samarkand region.

\author{
Рыжова Анастасия Петровна \\ аспирант, Санкт-Петербургский \\ государственный университет \\ ot_chan@mail.ru
}

Аннотация: Статья посвящена торжествам в честь 300-летия династии Романовых в Сырдарьинской, Ферганской и Самаркандской областях. На основе архивных документов и периодической печати воссозданы юбилейные мероприятия у русского населения и у «туземцев». Они должны были способствовать слиянию Туркестанского края с другими частями империи. Местное население пассивно, но с интересом участвовало в празднике «Белого Царя».

Ключевые слова: коммеморативная политика, династия Романовых, 300-летний юбилей династии, Узбекистан, Сырдарьинская область, Ферганская область, Самаркандская область.
$\mathrm{B}$ ласти Российской империи проводили национальную политику в Туркестанском генерал-губернаторстве в соответствии со своей главной задачей - постепенным слиянием края с остальными частями империи [15, с. 126]. Коммеморативная политика являлась элементом управления, с помощью которого возможно было сформировать из кочевников верных подданных русского царя. Праздник в честь 300-летия дома Романовых в 1913 г. по причине объявленной «всенародности», отмечался и на территориях современного Узбекистана с вниманием к «туземному» населению. Изучить эти празднества у далеких от русской культуры «туземцев» удалось с помощью периодической печати и архивных материалов фондов РГИА, а именно, отчетов местной власти о проведенных торжествах в Сырдарьинской, Ферганской и Самаркандской областях. Со страниц официальных источников прослежена и реакция «туземного» населения, которое не было однородным и «делилось даже на фракции и группы, из которых две главнейшие, сарты и киргизы, издавна находились в отношениях племенного антагонизма» [8, с. 15].

Основные юбилейные мероприятия проходили в Ташкенте, который на тот момент был довольно благоустроен и поражал «не только иногородних туземцев края, а также бухарцев и хивинцев, но и заезжего русского путешественника, с чистыми в летнее время тротуарами и мощенными улицами, с прекрасными школами, с электрическим трамваем и телефоном, с электриче- ским и керосино-калильным освещением, с кипящими жизнью базарами и с великолепными уличными насаждениями и садами, с красивыми зданиями и памятниками, с учеными, спортивными и благотворительными обществами, с театрами и газетами» [5, с. 27]. Начальник Ташкента полковник А.О. Завитневич в своем отчете указал лишь то, что все сведения о празднике 21 февраля в городе подробно описаны в статьях газет «Туркестанские Ведомости» и «Туркестанский Курьер». В этот день в «русской части города» здания приобрели торжественный вид. Крестные ходы из разных церквей следовали к Спасо-Преображенскому военному собору на литургию. В ней участвовали главный начальник края, генерал от кавалерии А.В. Самсонов, разные чины и другие молящиеся из числа горожан. После литургии состоялся военный парад, был зачитан Высочайший манифест и специально подготовленная к этому дню молитва [16].

Затем раздался пушечный салют, и к главному начальнику края подходили депутации «от городского самоуправления, от мещанского общества, от русского Никольского поселка Ташкентского уезда, от туземного населения, от местных армян и от туземных евреев». Особый интерес вызывает приветствие от крестьян поселка Никольского: «г. Генерал-Губернатор выразил удовольствие по тому поводу, что крестьяне довольны своей участью и благодарны Государю Императору за устройство их в крае и выразил пожелание скорее видеть весь край покрытым сетью русских благоденствую- 
щих поселков, лишь тогда можно будет с уверенностью сказать, что край сольется в одно с нашим государством и сделается вполне русским».

С речью от «туземного» населения выступил «почетный старик» Ишан-Хан Сеид Махмудханов: «В течение многих веков наш Туркестанский край населяли враждебные племена, которые постоянно вели борьбу между собой. Было тяжелое время, когда люди и имущество не были гарантированы спокойствием даже на один час. Но с подчинением туркестанского края под скипетр русского Царя, население познало все благо спокойной жизни, люди занялись своим ремеслом и вполне уверены в том, что в завтрашний день и в следующие года не могут лишиться своего имущества, они с чувством глубокой благодарности сознают ту пользу, которую имеют от перемены Правительства, и стараются поддержать тот лестный отзыв Вашего Высокопревосходительства, который очень их обрадовал, когда в последний проезд Великого Князя Константина Константиновича Вы изволили доложить Его Императорскому Высочеству о полном спокойствии всего населения». В конце своей речи он сказал, что в мечети Джами Старого города устраивают народные угощения для бедных и пригласил Самсонова на это мероприятие. Тот ответил благодарностью: «особенно приятно слышать сознание разницы между прежним бесправным положением и теперешнею уверенностью, что под сенью русских законов туземцы спокойны за свою личную неприкосновенность и за свое имущество, и видеть то искреннее чувство, с которым они относятся к настоящему торжеству». Обратившись ко всем старикам, Самсонов подметил, что они должны объяснять эту разницу своим детям, внукам и «воспитывать свое молодое поколение в заветах преданности русскому Царю». После завершения основных мероприятий ученики последовали в свои учебные заведения для проведения чтений, а высшие чины посетили бал в военном собрании. Более тысячи учеников русско-туземных школ после парада «разноцветной вереницей халатов и салей» отправились в «Народный Дом», где пропели гимн и молитву на сартовском языке, а затем были проведены чтения. Народное гулянье в городском саду не состоялось из-за плохой погоды, но вечером был дан фейерверк.

Старый город был достойно украшен, и на улицах наблюдалось большое оживление: «у сартов, одетых попраздничному, было заметно повышенное настроение, и они необычайно весело беседовали между собой». Весь день на улицах соблюдался порядок, «не было замечено ни одного пьяного сарта, что там для четверга составляет исключение». Днем в мечеть Джами прибыли многие высшие чины и почетные сарты [16]. Это культовое сооружение привлекало внимание многих путешественников: «С высоты этой мечети, известной также под названием Царской мечети, открывается великолепный вид на туземный Ташкент с его миниатюрными домика- ми под глиняными крышами». После землетрясений она была восстановлена на пожертвования Александра III [4, с. 3]. На угощение пришло много местного населения. Ученики меджелисских школ прочитали молитву за Царя и исполнили на русском языке гимн «Боже, Царя Храни!» В конце статьи автор добавил свои впечатления: «Вообще же по отношению к туземному городу можно сказать, что в праздновании знаменательного юбилея сарты не отставали от русской части города».

В местности Подшеват ташкентского уезда в честь юбилея был устроен поселок, которому дали название «Романовский». Кроме того, первое Ташкентское русско-туземное 2-классное училище переименовали в «Романовское» [7]. Русско-туземное учебное заведение было «одним из могущественных средств для сближения покоренных инородцев с русскими и для поднятия их умственного и нравственного уровня до той степени, при которой возможно восприятия европейской цивилизации» [9]. Большинство сартов с неохотой отдавали своих детей в русско-туземные школы «будучи народом, тесно замуравленым в рамки религии, выражавшейся иногда в остром нетерпимом фанатизме к русским» [1]. В данные заведения детей все-таки отдавали по причине важности знания русского языка. Гласный ташкентской городской думы Сеид Керим-Сеид Азимбаев под предлогом 300-летнего юбилея династии подал заявление на имя директора Алексеевского коммерческого училища, в котором он описывает свои впечатления от этого учебного заведения: «Род наш всегда был предан русским Царям и отец мой, оказавший важные услуги Русскому Правительству, завещал нам, детям своим, верность и благовейную преданность нашим государям. Сын мой, окончивший 4 класса вверенного вашему превосходительству училища ныне с успехом ведет мое большое торгово-промышленное дело и является прекрасно-воспитанным, серьезным и нравственным человеком, преданным родине и Царю. Я счастлив, что имею возможность своих детей учить в русских учебных заведениях, где они могут получить надлежащее воспитание и образование». Он пожертвовал деньги на сооружение бюста наследника Алексея Николаевича при училище, который, по его словам, должен нести значительную смысловую нагрузку: «бюст Царственного отрока должен иметь особенное воспитательное значение для обучающейся молодежи, поддерживая в них великое чувство любви к отечеству и к своим обожаемым Государям» [6].

На следующий день торжества продолжались. В здании уездного правления состоялся праздничный обед, на который были приглашены «старосты русских селений и некоторые почетные сельчане, волостные управители и некоторые заслуженные туземцы». Комнаты были украшены флагами и портретами Николая II и Александры Федоровны. Для «туземцев накрыт и сервирован был стол на коврах с обильным достарханом; для представителей русского населения стол накрыт был по- 
русски с водкой, винами и проч.». Основными блюдами были традиционные русские пироги и плов. Начальник уезда произнес речь, в которой обратился с благодарностью к слушателям и предложил «туземцам» уезда построить по школе в каждой волости: «Эти школы помогут туземному населению лучше исполнить свой долг послужить своей родине, и приобщиться ко всем благам ее, зная государственный язык родины». Автор статьи заканчивает описание обеда следующими словами: «Туркестан теперь уже часть дорогой России - нужен ей и служит уже ее украшением». В отчете ташкентского уездного начальника описывается то, как по всему уезду были устроены «туземные» игры «Байга» и др. Также в уездном управлении в память о юбилее был введен праздник 21 февраля [12, л. 5 об.].

Отдельного упоминания заслуживает издание, приуроченное специально к юбилейному дню киргизскими учителями и поэтом Шади Джанкуровым - первая книга на киргизском языке «История - поэма царствования Дома Романовых». В книге стихами кратко изложена история династии: «Задай же вопрос, кто наш Государь, И вы получите ответ: белый царь. Спросите о царской династии - И почти никто не в состоянии дать вам ответа» [14]. Автором статьи, где описывается эта книга, указывается, что «язык книжки удобопонятен и для сартов и для узбеков».

В городе Скобелев Ферганской области отметили юбилей сходным с Ташкентом образом. Интересно то, что на следующий день, 22 февраля, с помощью местной администрацией состоялась закладка «музея-библиотеки в память 300-летия царствования Дома Романовых» [3]. Отдельное внимание стоит уделить мероприятиям в уездах этой области. В главной мечети Старый Маргелан В присутствии большого количества народа были прочитаны молитвы «о здравии Царствующего Дома» [13, л. 12]. В «Ферганских областных ведомостях» подробно описано литературный утренник в Янги-Курганской русско-туземной школе Наманганского уезда. Заведующим школой была произнесена речь, которая сразу переводилась на сартовский язык. Речь «произвела на слушателей - туземцев глубокое впечатление, оставив в их памяти хорошее, светлое представление об истории русского государства» [2]. Ученики пели песни, читали стихи и разные статьи на русском и сартовском языках. По мнению автора, так как «туземцы» впервые присутствовали на подобном мероприятии, они отнеслись к нему с боль-

\section{шим интересом.}

В празднично украшенном Самарканде все основные торжества прошли по уже устоявшемуся ритуалу [11, л. 64]. Интересно то, что ходжентский уездный начальник в своем отчете отметил то, что праздник отмечался только в русских поселках уезда, а в «туземных» кишлаках празднования не проводились [11, л. 69]. Не так часто в газетах можно встретить описания праздника в тюрьмах. В ташкентской тюремной церкви была совершена литургия, после которой прокурор окружного суда Б.Ю. Рахальский объявил 65 арестантам, что они подлежали освобождению в силу Высочайшего манифеста. Многим другим заключенным срок был сокращен. 21 февраля находящиеся в карцере были освобождены, для всех арестантов было улучшено питание, увеличено время прогулки и разрешены свидания [10]. В Скобелеве в тюремной церкви на молебне присутствовали православные арестанты вместе с прокурорами, начальником тюрьмы А.Т. Шарыбиным и его помощником. Заключенные-мусульмане были выведены в тюремный двор, «где приглашенный мулла совершил благодарственное моление». 35 арестантов было освобождено, срок остальным заключенным сокращен, и в этот день улучшено питание [17].

В 1913 г. местные власти пытались внушить «туземцам», что они должны быть «готовы положить жизнь за дорогую Родину и за нашего Великодержавного императора» [2]. Администрация пыталась также вызвать патриотические настроения среди «туземного» и русского населения с помощью легенд и описания «великого прошлого» представителей династии. В связи с тем, что праздник в честь 300-летнего юбилея дома Романовых был всероссийским, описания торжеств стекались в петербургский Комитет для устройства празднования трехсотлетия Царствующего Дома Романовых со всей империи. Население Туркестана отнеслось ко всем юбилейным мероприятиям так же положительно, как и большинство населения империи. Однако его роль была скорее пассивной: «туземцы» были вовлечены в праздничные мероприятия в значительно меньшей степени, чем русские. Как бы ни хотели власти создать картину общенародного единства, у них это не получилось. В итоге русское население праздновало отдельно от «туземцев», многие из которых вообще не стали отмечать юбилей династии.

ЛИТЕРАТУРА

1. Андреев Гр. Зрелый вопрос русско-туземных школ // Туркестанский курьер. 1909. № 7.

2. Баранов К.В. Литературное утро в Янги-Курганской русско-туземной школе // Ферганские областные ведомости. 1913. № 53. С. 3.

3. К. Празднование 300-летнего юбилея дома Романовых в гор. Скобелев // Ферганские областные ведомости. 1913. № 50. С. 2.

4. Кастанье И.А. Поездка по Тургайской и Сыр-Дарьинской областям в 1906-1907 г. вдоль Ташкентской железной дороги. Оренбург: Тип. Мильберг, 1909. 67 с. 
5. Маллицкий Н.Г. Ташкент (Исторический очерк). Известия ташкентской городской думы Ташкент, 1915. 27 с.

6. Местные известия // Туркестанские ведомости. 1913. № 40. С. 5.

7. Местные известия // Туркестанские ведомости. 1913. № 32. С. 2.

8. Наливкин В.П. Туземцы раньше и теперь. Ташкент: Электрич. Типо-лит. «Турк. Т-ва Печатного Дела», 1913. 144 с.

9. Особенности русско-туземных школ // Туркестанский курьер. 1908. № 68.

10. Праздник в тюрьме // Туркестанские ведомости. 1913. Прибавление к № 44. С. 3.

11. Российский государственный исторический архив (далее - РГИА). Ф. 1320. 0п. 1. Д. 228.

12. РГИА. Ф. 1320. ОП. 1. Д. 237.

13. РГИА.Ф. 1320. Оп. 1. Д. 253.

14. Утегенев С. 300-летнй юбилей Царствования Дома Романовых и киргизы // Туркестанские ведомости. 1913. № 44. С. 4.

15. Центральная Азия в составе Российской империи / под ред. С. Абашина, Д. Арапова, Н. Бекмаханова и др. М.: Новое литературное обозрение, 2008. $451 \mathrm{c.}$

16. Шумилов В. Празднование 300-летнего юбилея Дома Романовых в Ташкенте // Туркестанские ведомости. 1913. № 44. С. 3.

17. Юбилейные торжества в г. Скобелеве // Ферганские областные ведомости. 1913. № 47. С. 3.

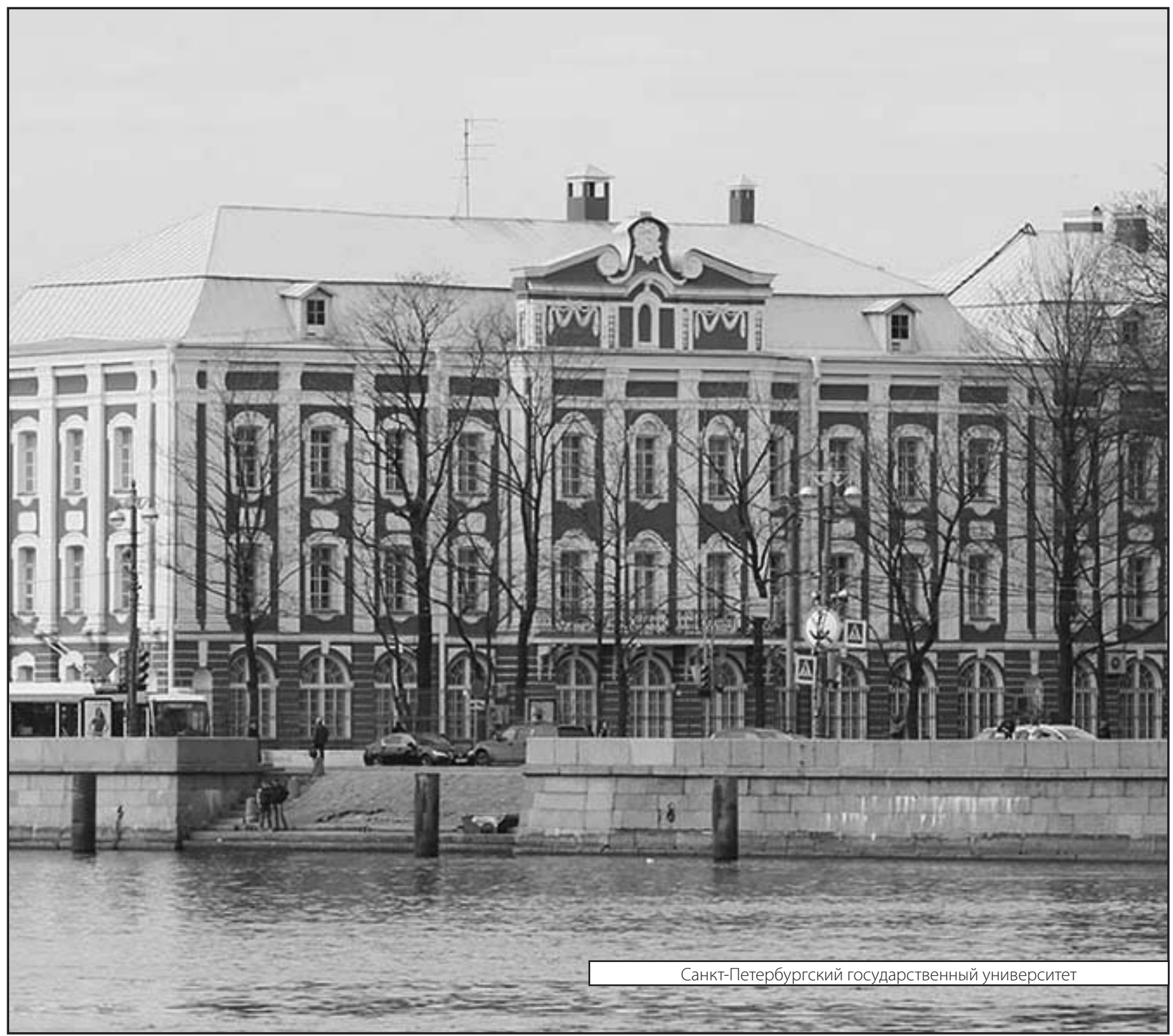

